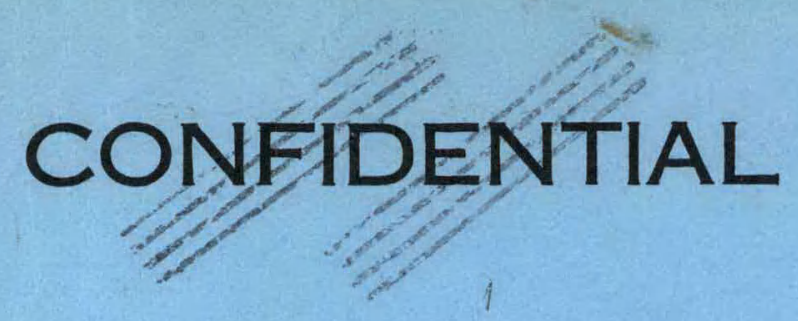

\title{
MICLASOHE
}

HW- 44744

AEC RESEARCH AND DEVELOPMENT REPORT CHEMISTRY - TRANSURANIC ELEMENTS

COPY NO.

\section{ABSORPTION SPECTRA OF PLUTONIUM AND IMPURITY IONS IN NITRIC ACID SOLUTION}

\author{
BY \\ M. N. MYERS \\ SEPARATIONS TECHNOLOGY SECTION \\ ENGINEERING DEPARTMENT
}

JULY 31, 1956

THIS DOCUMENT COKTAINS CONFIDENTIAL-RESTRICTED DATA

RELATING TO CIVILIAN APPLICATION OF ATOMIC ENERGY.

HANFORD ATOMIC PRODUCTS OPERATION

RICHLAND, WASHINGTON

\section{GENERAL ELECTRIC}

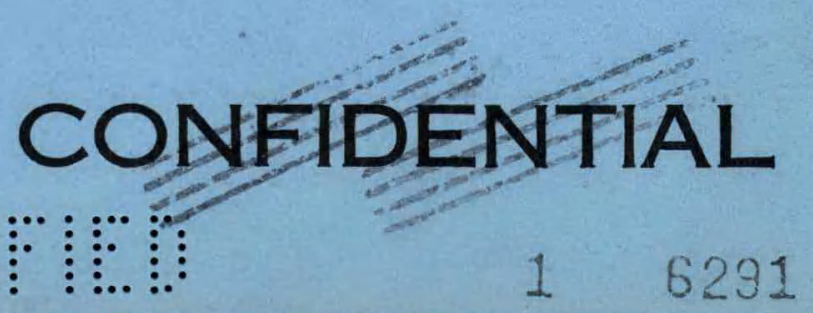


LEGAL NOTICE

This report was prepared as an account of Government sponsored work. Neither the United States, nor the Commission, nor any person acting on behalf of the Commission:

A. Makes any warranty or representation, express or implied, with respect to the accuracy, completeness, or usefulness of the information contained in this report, or that the use of any information, apparatus, method, or process disclosed in this report may not infringe privately owned rights; or

B. Assumes any liabilities with respect to the use of, or for damages resulting from the use of any information, apparatus, method, or process disclosed in this report.

As used in the above, "person acting on behalf of the Commission" includes any employee or contractor of the Commission to the extent that such employee or contractor prepares, handles or distributes, or provides access to, any information pursuant to his employment or contract with the Commission. 


\section{DISCLAIMER}

This report was prepared as an account of work sponsored by an agency of the United States Government. Neither the United States Government nor any agency Thereof, nor any of their employees, makes any warranty, express or implied, or assumes any legal liability or responsibility for the accuracy, completeness, or usefulness of any information, apparatus, product, or process disclosed, or represents that its use would not infringe privately owned rights. Reference herein to any specific commercial product, process, or service by trade name, trademark, manufacturer, or otherwise does not necessarily constitute or imply its endorsement, recommendation, or favoring by the United States Government or any agency thereof. The views and opinions of authors expressed herein do not necessarily state or reflect those of the United States Government or any agency thereof. 


\section{DISCLAIMER}

Portions of this document may be illegible in electronic image products. Images are produced from the best available original document. 
This document classified by

H. H. Hopkins, Jr。
HW -44744

Chemistry - Transuranic Elements $\left(\mathrm{M}-3679,18\right.$ th $\left.\mathrm{Ed}_{\text {。 }}\right)$

\section{ABSORPTION SPECTRA OF PLUTONIUM AND IMPURITY IONS IN NITRIC ACID SOLUTION}

By

M. N. Myers

234-5 Development Unit

Plant Processes Sub-Section

July 31, 1956

\section{HANFORD ATOMIC PRODUCTS OPERATION RICHLAND, WASHINGTON}

Work performed under Contract \#W-31-109-Eng-52 between the Atomic Energy Commission and General Electric Company

Cassmention canceled (or changed to

UNCLASSIFIED

P) Lated

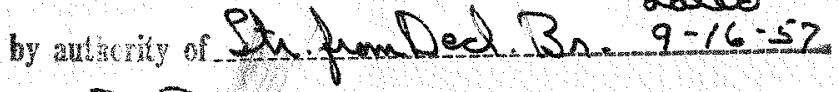

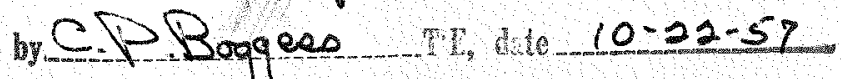




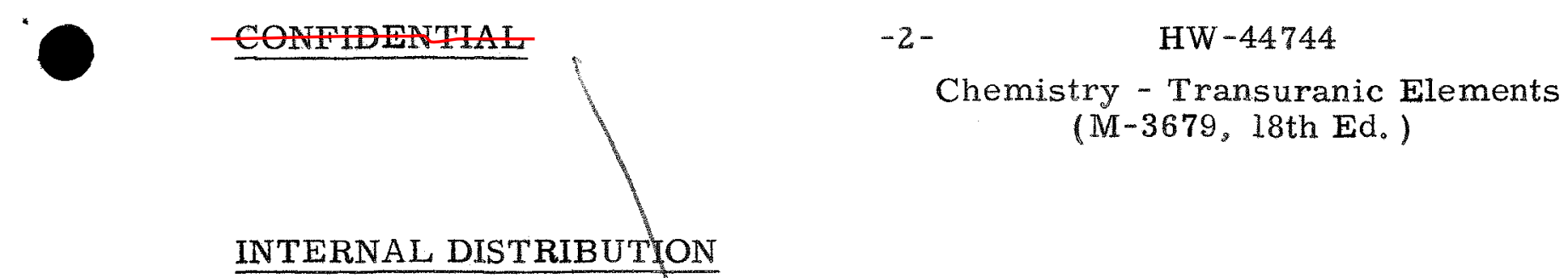

\section{Copy Number}

1

W. G. Browne

2
3

3

5

6

7

8

9

10

$11-12$

13

14

15

16

K. M. Harmon

O. F. Hill

H. H. Hopkins

M。 N. Myers

W. H. Reas

R. B. Richards

R. C. Smith

R. E. Smith

E. E。 Voiland

Extra

300 File Copy

Record Center

COD, HAPO - Patent Branch, Washington

COD, HAPO - Responsible Reviewer

$17-24$ HAPO - Declassification Branch, Oak Ridge COD, HAPO - Declassification Branch, Oak Ridge 


\section{ABSORPTION SPECTRA OF PLUTONIUM AND IMPURITY IONS IN NITRIC ACID SOLUTION}

\section{INTRODUCTION}

The determination of the valence states of plutonium is desirable in various parts of the process for the separation and purification of plutonium. During the early history of plutonium chemistry, a considerable amount of work was done on the spectra of plutonium ions in various valence states and some of the complexes. With the exception of studies summarized by Hindman, (1) most of this work was done with solutions other than nitric acid。 Since the separations process is carried out in nitric acid solutions, and little is reported on the spectra of many of the impurities which are present in the process, an investigation was undertaken to determine the absorption coefficients for plutonium valence species in nitric acid, and for some of the impurities found in process streams. A Beckman DK-2 recording spectrophotometer was used.

\section{SUMMARY AND CONCLUSIONS}

The absorption spectra for plutonium(III), (IV), (VI), and the red plutonium(IV) - peroxy complex were determined in nitric acid solution. Extinction coefficients for the above species of plutonium were measured. Temperature has little effect on the spectra, but variation of acidity causes shifting of absorption peaks and some changes in the extinction coefficients.

The absorption spectra and extinction coefficients in the region 390-1200 mu were measured for chromic, nickelous, manganous, calcium, lanthanum, aluminum, ferrous, ferric, and permanganate ions in nitric acid solutions. In addition, the effects of nitrite, oxalic acid, sulfamic acid, hydrogen peroxide, and various nitric acid concentrations on the extinction coefficients of some of these ions were determined. The chromic, nickelous, ferrous, and permanganate ions, and ferric ion with oxalic acid, 
have sufficiently high extinction coefficients to cause inaccuracies in valence determinations of plutonium in solutions containing high concentrations of these ions, unless corrections are made.

EXPERIMENTAL

Valence Adjustment

A solution of plutonium nitrate containing 100 per cent plutonium(IV) was prepared by adding hydrogen peroxide (final concentration, three per cent by volume) to pure stock solution $\left(500 \mathrm{~g} / 1\right.$ plutonium, $4 \mathrm{M}_{\mathrm{HNO}}$ ) and allowing the mixture to react completely (ca. twenty minutes). Plutonium (III) was prepared from plutonium(IV) by reduction with stoichiometric amounts of ferrous ion, using $0.1 \mathrm{M}$ sulfamic acid as a holding agent. Plutonium(VI) was prepared by boiling a 1.0 M nitric acid solution of plutonium(IV) $(30 \mathrm{~g} / 1$ plutonium) for several hours under reflux. Plutonium (IV)-peroxy complex was obtained by adding hydrogen peroxide (final concentration, $0.27 \mathrm{M})$ to plutonium(IV) solution $(0.5-1 \mathrm{~g} / 1$ plutonium) at $0 \mathrm{C}$.

Equipment

A Beckman DK-2 Recording Spectrophotometer, with $10 \mathrm{~mm}$ square Corex cells, was used for all experiments. A special sample chamber utilizing quartz windows was used to prevent contamination of the spectrophotometer.

Analysis

All analyses were made in the 234-5 Control Laboratory. Plutonium was determined by radio-assay. Experiments were run at 21-25 C except those with the peroxy complex, which were run at 10-15 C.

\section{RESULTS AND DISCUSSION}

Plutonium

As previously reported, ${ }^{(1)}$ plutonium(III), (IV), and (VI) follow the Beer-Lambert law in their light absorbing characteristics. The plutonium(VI) 
peak at $829 \mathrm{~m} \mu$, however, deviates markedly, as shown in Figure 1. The absorption spectra of these three valence states are shown in Figure 2, and DK-2 plots of the valence states are shown in Figures 6, 7, and 8, respectively. For all of the absorption peaks except the $829 \mathrm{m \mu}$, an average extinction coefficient was determined from absorption measurements made over the concentration range $0.5-3 \mathrm{~g} / 1$ plutonium.

The absorption spectra of the plutonium(IV)-peroxy complex does not differ greatly from the plutonium(IV) spectra at wavelengths greater than $650 \mathrm{~m} \mu$ but has very strong absorption in the shorter wavelength region, as shown in Figure 9. The peroxy complex extinction coefficients were determined at plutonium concentrations of 0.5 and $1 \mathrm{~g} / 1$. At the nitric acid concentration used ( $2 \underline{M})$, a very large peroxide to plutonium(IV) ratio (approximately 135/1) was necessary for complete complexing of the plutonium(IV). Further addition of peroxide resulted in no change in absorption. The red peroxy complex had an absorption spectrum similar to that previously reported. (1) No brown peroxy complex was observed in $2 \mathrm{M}$ nitric acid. The extinction coefficients obtained for the plutonium(IV) peroxy complex hold over the range 0.5-135 moles of peroxide/mole of plutonium, as shown by material balances. Uncomplexed plutonium(IV) can be determined quantitatively in the presence of complexed plutonium(IV) from the 475 mpe peak.

Table I shows the molar extinction coefficients of plutonium(III), (IV), (VI), and the red plutonium(IV)-peroxy complex, as determined for the DK-2 used. These values may vary slightly for other machines because of different characteristics of the individual spectrophotometers. No correction for ferric iron absorption is made on the plutonium(III) peaks, since the absorption is negligible for the small amount of iron $(0.5 \mathrm{~g} / 1)$ present.

Concentrations as low as $0.1,0.05,0.01$, and $0.02 \mathrm{~g} / 1$ plutonium(III). (IV). (VI), and (IV)-peroxy complex can be measured in the presence of each other, in mixtures containing a total of about $3 \mathrm{~g} / 1$ plutonium, in a $10 \mathrm{~mm}$ cell. At these low concentrations precision is no better than a 
factor of two. However, at higher concentrations of the individual ions (up to $3 \mathrm{~g} / 1$ ), the precision is approximately $\pm 0.1, \pm 0.05$, and $\pm 0.1 \mathrm{~g} / \mathrm{l}$ plutonium for the III, IV, and VI states. The presence of absorbing impurities decreases the precision. The DK-2 spectrophotometer itself has a duplication limit of \pm 0.005 absorbance, or for typical peaks \pm two per cent。

The maximum concentration which may be used for valence determination in $10 \mathrm{~mm}$ cells is $3-3.5 \mathrm{~g} / \mathrm{l}$. Concentrations below $0.3 \mathrm{~g} / \mathrm{l}$ or above $3 \mathrm{~g} / 1$ require longer or shorter cells, respectively。

Small temperature differences have little effect on the extinction coefficients or spectra of plutonium(III) or (VI) and cause only a slight change in two absorption peaks (702 $\mathrm{m} \mu, 475 \mathrm{~m} \mu)$ in the plutonium(IV) spectra. (A maximum error of plus four per cent in calculation results from a temperature change from 15 to $30 \mathrm{C}$ ).

As previously reported ${ }^{(1)}$ variation in the nitric acid concentration causes shifting of absorption peaks, the appearance of a new peak for plutonium(VI) at high acidities, and some increase or decrease of the extinction coefficients. Tables II, III, and IV show the absorption coefficients for plutonium(III), (IV), and (VI) at various acidities. These values are only good to \pm 5 per cent, although the precision within each valence state is probably better. Several discrepancies greater than five per cent are seen on comparison with Table I. No explanation is available, but it is proposed that absorption standards be checked frequently to assure that the machine response does not vary over particular absorption ranges, following periods of maintenance.

Other Ions

The extinction coefficients of calcium, lanthanum, manganous and aluminum ions are so very low that up to ten grams per liter of these ions can be ignored in most valence determinations of plutonium. 
Chromic ion has two strong absorption peaks in the region 390-1200 $\mathrm{m} \mu$ at 405 and $575 \mathrm{~m} \mu$. Nickelous ion has absorption peaks at 394, 655, 670, $1180 \mathrm{~m} \mu$ (Figure 3). No changes due to temperature, oxalic acid, sulfamic acid, nitrite, hydrogen peroxide, or nitric acid concentration in the region 0.5 to $6 \underline{M}$ were observed with these ions.

Permanganate ion in $2 \underline{M}$ nitric acid has very strong absorption at 450-600 $\mathrm{m \mu}$, with peaks at 506, 523,542, and $562 \mathrm{~m} \mu$ and possibly peaks at 467 and $490 \mathrm{~m} \mu$, as shown in Figure 10 .

Ferrous iron has absorption peaks at 960 and $1100 \mathrm{~m} \mu$ (Figure 4). Oxalic acid ( $0.1 \mathrm{M}$ ), nitric acid concentration (between 0.5 and 6.0 $\mathrm{M} \mathrm{HNO}_{3}$ ) and sulfamic acid have very little effect on either the absorption spectra or coefficients. Nitrite forms a complex with ferrous ion which absorbs strongly at wavelengths shorter than $800 \mathrm{m \mu}$, but is too short-lived in $2 \underline{M}$ nitric acid to obtain a spectrum.

Ferric iron has very low absorption in the range 450-1200 $\mathrm{m} \mu$. Below $450 \mathrm{~m} \mu$, absorption increases rapidly. Nitrite, hydrogen peroxide, and sulfamic acid have very little effect on the extinction coefficients. The extinction coefficients increase slightly with increasing acidity. Oxalic acid forms a complex with ferric iron, which absorbs strongly at wavelengths shorter than $500 \mathrm{~m} \mu$, as shown in Figure 5.

A summary of the extinction coefficients of the above ions is found in Table V. Chromic, nickelous, ferrous, and ferric ions follow the BeerLambert Law。

$\mathrm{MNM}_{\circ}$ ag

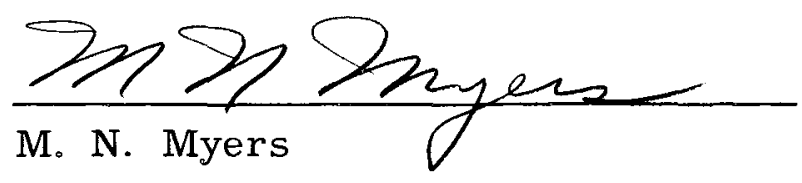




\section{REFERENCES}

(1) Hindman, J. C., "Ionic and Molecular Species of Plutonium in Solution," National Nuclear Energy Series, Vol. IV-14A. The Actinide Elements,

G. T. Seaborg and J. J. Katz, Ed. New York: McGraw-Hill, (1954) pp. $301-364$. 


\section{TABLE I}

MOLAR EXTINCTION COEFFICIENTS OF PLUTONIUM(III), (IV), (VI), AND (IV)-PEROXY COMPLEX

\begin{tabular}{|c|c|c|c|c|}
\hline \multirow[b]{2}{*}{$\begin{array}{l}\text { Wavelength } \\
\mathrm{m \mu}\end{array}$} & \multicolumn{4}{|c|}{ Molar Extinction Coefficients $(\mathrm{a})$} \\
\hline & Plutonium(III) & Plutonium(IV) & $\underline{\text { Plutonium(VI) }}$ & $\begin{array}{l}\text { Plutonium(IV)- } \\
\text { Peroxy Complex } \\
\end{array}$ \\
\hline 421 & 18.4 & 33.0 & 18.6 & 247 \\
\hline 457 & 7.6 & 26.5 & 22.0 & 197 \\
\hline 475 & 7. 6 & 81.7 & 21. 3 & 193 \\
\hline 502 & 6.4 & 15.3 & 17.4 & 304 \\
\hline 541 & 21.7 & 23.2 & 10.8 & 176 \\
\hline 565 & 45.4 & 9.8 & 7.7 & 89 \\
\hline 598 & 44.7 & 7.7 & 6.5 & 40.6 \\
\hline 656 & 17.0 & 39.0 & 6.7 & 31.5 \\
\hline 702 & 3.6 & 19.8 & 5.0 & 22.9 \\
\hline 795 & 18.2 & 26.0 & 6.5 & 25.1 \\
\hline 829 & 10.0 & 14.3 & $\operatorname{Graph}^{(b)}$ & 20.1 \\
\hline 850 & 7.9 & 20.3 & 5.7 & 17.4 \\
\hline 908 & 24.9 & 4.1 & 4.5 & 9.1 \\
\hline 950 & 5.7 & 5.3 & 25.8 & 10.5 \\
\hline 981 & 7.4 & 11.2 & 21.3 & 17.0 \\
\hline 1017 & 18.4 & 17.4 & 4.5 & 22.7 \\
\hline 1068 & 13.4 & 34.6 & 2.9 & 26.1 \\
\hline 1101 & 25.3 & 19.1 & 2.5 & 15.5 \\
\hline
\end{tabular}

NOTES:

(a) Determinations were made in $2 \underline{\mathrm{M}} \mathrm{HNO}_{3}$.

(b) Figure 1 shows the molar extinction coefficient variation with absorbance. 
TABLE II

EFFECT OF ACIDITY ON ABSORPTION SPECTRA AND COEFFICIENTS OF PLUTONIUM(III)

\begin{tabular}{|c|c|c|c|c|}
\hline \multirow{2}{*}{$\begin{array}{l}\text { Wavelength } \\
\mathrm{m} \mu\end{array}$} & \multicolumn{4}{|c|}{ Molar Extinction Coefficients in } \\
\hline & $0.52 \mathrm{M} \mathrm{HNO}_{3}$ & $2.12 \mathrm{M} \mathrm{HNO}_{3}$ & $3.92 \mathrm{M} \mathrm{HNO}_{3}$ & $5.79 \mathrm{M} \mathrm{HNO}_{3}$ \\
\hline 565 (a) & 48 & 47 & 49 & 49 \\
\hline 598 & 45 & 47 & 48 & 48 \\
\hline 662 & 19 & 17 & 16 & 16 \\
\hline 808 & 20 & 18 & 17 & 16 \\
\hline 908 (b) & 25 & 24 & 23 & 23 \\
\hline 1017 & 19 & 18 & 16 & 16 \\
\hline 1101 & 27 & 25 & 23 & 22 \\
\hline
\end{tabular}

NOTES:

(a) This peak shifted from $568 \mathrm{~m} \mu$ at $0.52 \underline{M ~ H N O}_{3}$ to $563 \mathrm{~m} \mu$ at $5.79 \underline{\mathrm{M} \mathrm{HNO}} \mathrm{HN}_{3}$. (b) This peak shifted from $908 \mathrm{~m} \mu$ at $0.52 \underline{\mathrm{MNO}}_{3}$ to $916 \mathrm{~m} \mu$ at $5.79 \underline{\mathrm{M} \mathrm{HNO}} \mathrm{HN}_{3}$.

T ABLE III

EFFECT OF ACIDITY ON ABSORPTION SPECTRA AND COEFFICIENTS OF PLUTONIUM(IV)

\begin{tabular}{|c|c|c|c|c|}
\hline \multirow{2}{*}{$\begin{array}{l}\text { Wavelength } \\
\mathrm{m} \mu\end{array}$} & \multicolumn{4}{|c|}{ Molar Extinction Coefficients in } \\
\hline & $0.52 \underline{\mathrm{M}} \mathrm{HNO}_{3}$ & $2.0 \underline{\mathrm{M}} \mathrm{HNO}_{3}$ & $3.93 \mathrm{M} \mathrm{HNO}_{3}$ & $5.96 \underline{\mathrm{MNO}} 3$ \\
\hline 421 (a) & 26 & 32 & 39 & 38 \\
\hline 475 & 81 & 91 & 94 & 79 \\
\hline $541(\mathrm{~b})$ & 21 & 22 & 24 & 24 \\
\hline 656 & 40 & 40 & 43 & 40 \\
\hline 702 & 20 & 19 & 21 & 21 \\
\hline 795 (c) & 27 & 26 & 27 & 26 \\
\hline 850 & 17 & 19 & 21 & 19 \\
\hline 1068 & 34 & 35 & 38 & 38 \\
\hline
\end{tabular}

NOTES:

(a) This peak shifted from $425 \mathrm{~m} \mu$ at $0.52 \underline{\mathrm{M} \mathrm{HNO}}_{3}$ to $421 \mathrm{m \mu}$ at $5.96 \underline{\mathrm{M} \mathrm{HNO}}$.

(b) This peak shifted from $546 \mathrm{m \mu}$ at $0.52 \underline{\mathrm{M} \mathrm{HNO}}_{3}$ to $538 \mathrm{m \mu}$ at $5.96 \underline{\mathrm{M}} \mathrm{HNO}_{3}$.

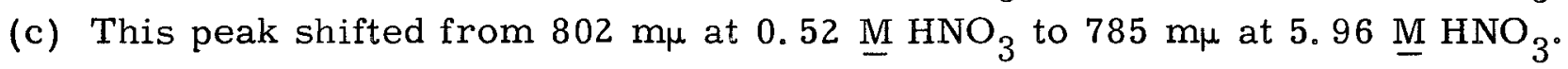


T ABLE IV

EFFECT OF ACIDITY ON ABSORPTION SPECTRA AND COEFFICIENTS OF PLUTONIUM(VI)

\begin{tabular}{|c|c|c|c|c|}
\hline \multirow{2}{*}{$\begin{array}{c}\text { Wavelength } \\
\mathrm{m \mu}\end{array}$} & \multicolumn{4}{|c|}{ Molar Extinction Coefficients in } \\
\hline & $0.62 \mathrm{MINO} 3$ & $2.06 \mathrm{M} \mathrm{HNO}$ & $3.95 \mathrm{M} \mathrm{HNO}$ & $5.55 \mathrm{M} \mathrm{HNO}_{3}$ \\
\hline 457 & 17 & 18 & 21 & 23 \\
\hline 785 & 4.7 & 4.7 & 4.8 & 5.5 \\
\hline 815 & 5.8 & 5.8 & 8.3 & $21(a)$ \\
\hline $829(\mathrm{~b})$ & 117 & 114 & 118 & 118 \\
\hline 950 & 27 & 26 & 25 & 22 \\
\hline 980 & 21 & 21 & 20 & 18 \\
\hline
\end{tabular}

NOTES:

(a) This was a new peak.

(b) These values hold only for the concentration used for this particular run. 
TABLE V

MOLAR EXTINCTION COEFFICIENTS OF VARIOUS IONS IN 2 M HNO $_{3}$

\begin{tabular}{|c|c|c|c|c|c|c|c|c|c|}
\hline $\begin{array}{c}\text { Wavelength } \\
\mathrm{m \mu} \\
\end{array}$ & $\mathrm{Ni}^{+2(a)}$ & $\mathrm{Cr}^{+3(\mathrm{~b})}$ & $\mathrm{Fe}^{+2(\mathrm{c})}$ & $\mathrm{Fe}^{+3}$ & $\begin{array}{l}\mathrm{Fe}^{+3}+0.1 \mathrm{M} \\
\text { Oxalic Acid } \\
\end{array}$ & $\mathrm{MnO}_{4}{ }^{-(\mathrm{d})}$ & $\mathrm{Mn}^{+2}$ & $\mathrm{Al}^{+3}$ & $\mathrm{La}^{+3}$ \\
\hline 421 & 2.1 & 4.6 & 0.20 & 0.35 & & 120 & & & \\
\hline 457 & 0.32 & 2.9 & 0.13 & 0,05 & 20 & 210 & & & \\
\hline 475 & 0.20 & 3.5 & 0.11 & 0.05 & 9.2 & 640 & & $0.027(\mathrm{f})$ & $0.38(f)$ \\
\hline 502 & 0.16 & 9.1 & 0.10 & 0.0 & 2.6 & 1600 & & & \\
\hline 541 & 0.25 & 11.6 & 0.10 & 0.0 & 0.65 & 2090 & $.027(\mathrm{e})$ & & \\
\hline 565 & 0.32 & 10.7 & 0.10 & 0.0 & 0.36 & 1180 & & & \\
\hline 598 & 0.60 & 3.0 & 0.10 & 0.0 & 0.22 & 250 & & & \\
\hline 656 & 1.7 & 0.6 & 0.15 & 0.0 & 0.19 & 140 & & & \\
\hline 702 & 2. 0 & 0.0 & 0.22 & 0.01 & 0.15 & 70 & & & \\
\hline 795 & 1. 0 & 0.0 & 0.53 & 0.04 & 0.18 & 40 & & & \\
\hline 829 & 0.55 & 0.0 & 0.81 & 0.03 & 0.22 & & & & \\
\hline 850 & 0.36 & 0.0 & 1.0 & 0.02 & 0.25 & & & & \\
\hline 908 & 0.33 & 0.0 & 1.4 & 0.01 & 0.28 & & & & \\
\hline 950 & 0.50 & 0.0 & 1.5 & 0.01 & 0.27 & & & & \\
\hline 981 & 0.75 & 0.0 & 1.3 & 0.01 & 0.26 & & & & \\
\hline 1017 & 1.0 & 0.0 & 0.90 & 0.0 & 0.25 & & & & \\
\hline 1068 & 1. 5 & 0.0 & 1.2 & 0.0 & 0.25 & & & & \\
\hline 1101 & 1.7 & 0.0 & 1.2 & 0.0 & 0.25 & & & & \\
\hline
\end{tabular}

\section{NOTES:}

(a) Absorption peaks for nickelous ion are at 394,655, 670, $1180 \mathrm{~m} \mu$ with extinction coefficients of $4.5,1.7,1.7$, and 2.0 , respectively.

(b) Absorption peaks for chromic ion are at 405, and $575 \mathrm{m \mu}$, with extinction coefficients of 14.0 and 11.8 , respectively.

(c) Ferrous ion has absorption peaks at 960 and $1100 \mathrm{m \mu}$, with extinction coefficients of 1.5 and 1.38 respectively.

(d) Absorption peaks for permanganate ion are at 506, 523, 542, and $562 \mathrm{~m} \mu$ with extinction coefficients of $1650,2175,2090$, and 1220, respectively. At wavelengths longer than $702 \mathrm{~m} \mu$, the extinction coefficients drop sharply. 


\section{TABLE V (contd.)}

\section{NOTES (contd.)}

(e) Maximum absorption for manganous ion occurs at 400 and $538 \mathrm{~m} \mu$ with extinction coefficients of 0.092 and 0.027 , respectively. Extinction coefficients are nearly zero at other wavelengths between 400-1200 $\mathrm{m \mu}$.

(f) This is the maximum extinction coefficient for this ion. Extinction coefficients at other wavelengths between 400-1200 $\mathrm{m \mu}$ are slightly smaller.

(g) Absorption coefficients for calcium ion are zero in the wavelength range 400-1200 $\mathrm{m} \mu$. 


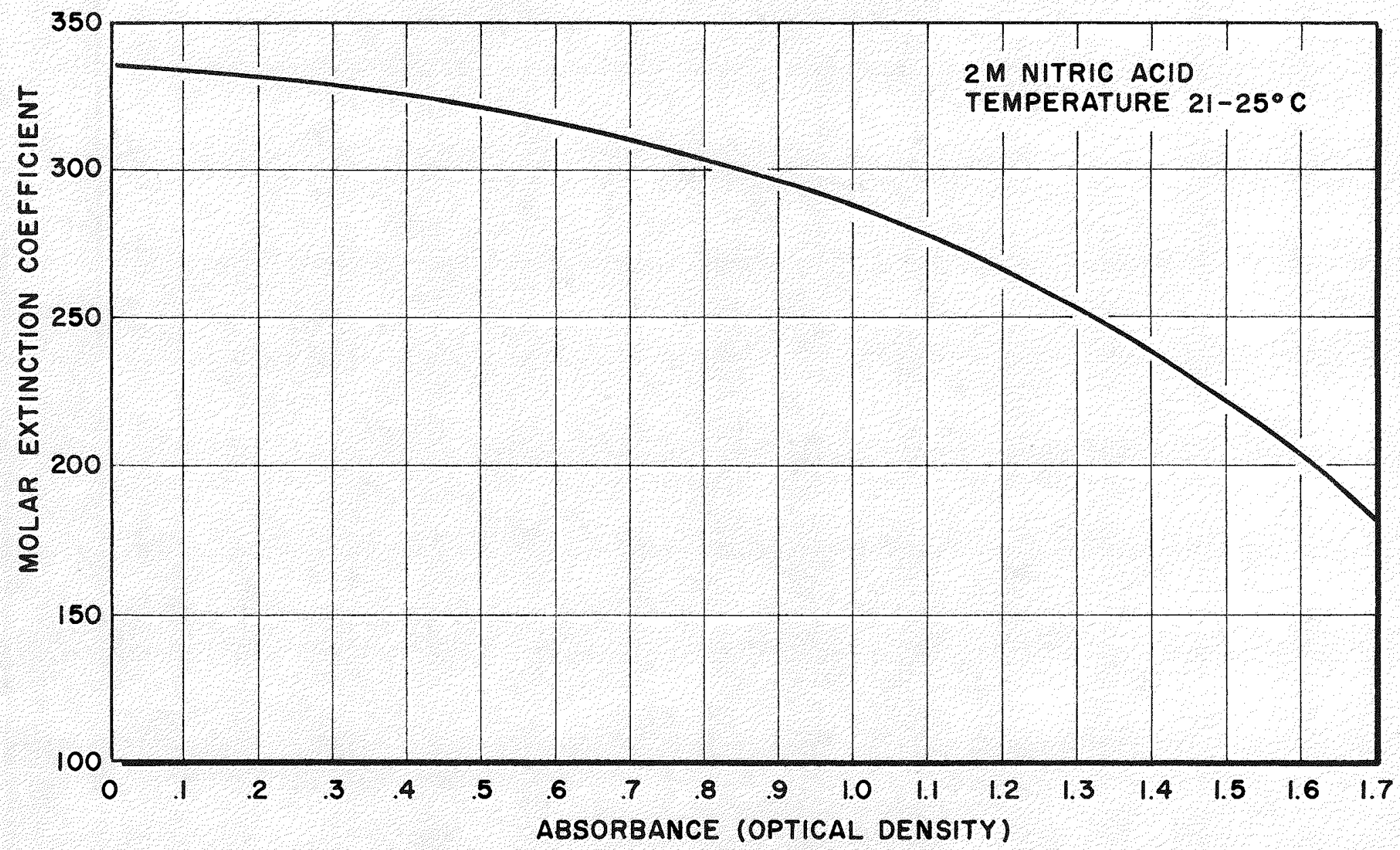

FIGURE 1

ABSORPTION OF PLUTONIUM(VI) AT $829 \mathrm{~m}_{\mu} 2 \mathrm{M} \mathrm{HNO}_{3}$ 


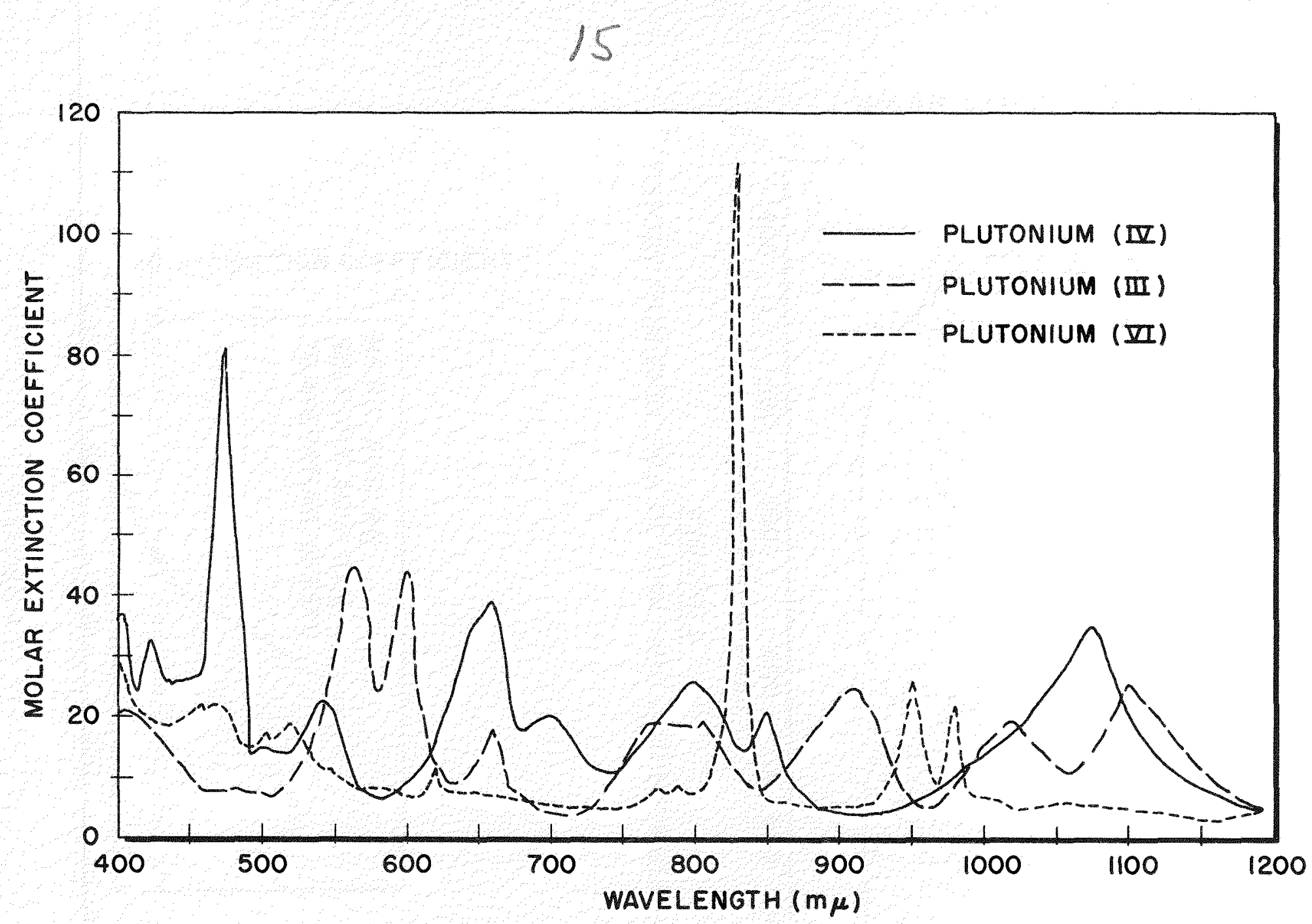

FIGURE 2

ABSORPTION SPECTRA OF PLUTONIUM(II), (IV), AND (VI) IN $2 \mathrm{M} \mathrm{HNO}_{3}$ AT 21-25 C 


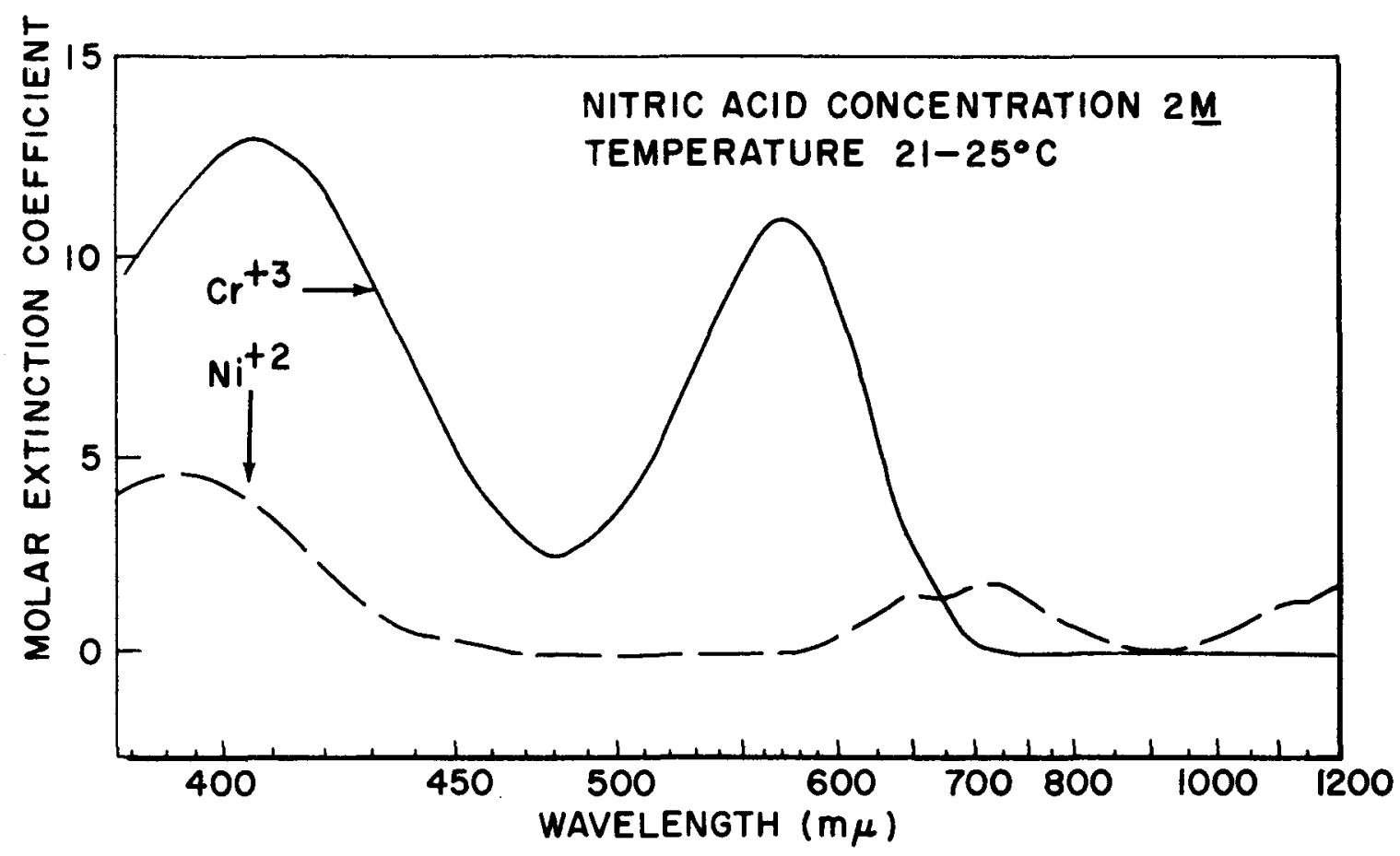

FIGURE 3

ABSORPTION SPECTRA OF CHROMIC AND NICKELOUS IONS

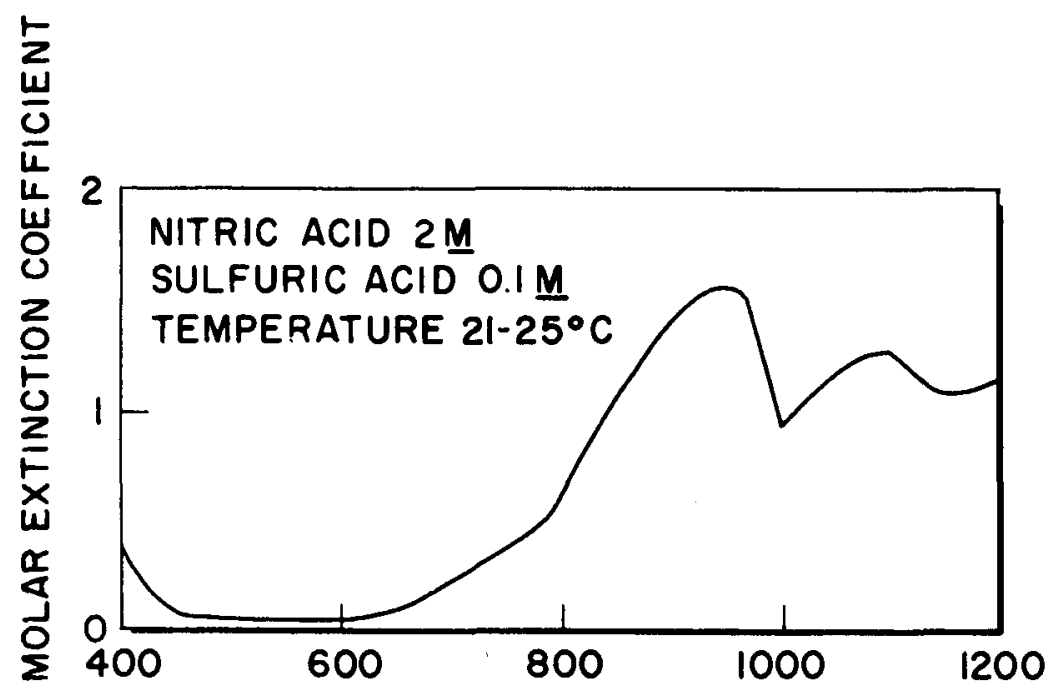

F IGURE 4

ABSORPTION SPECTRA OF FERROUS ION 


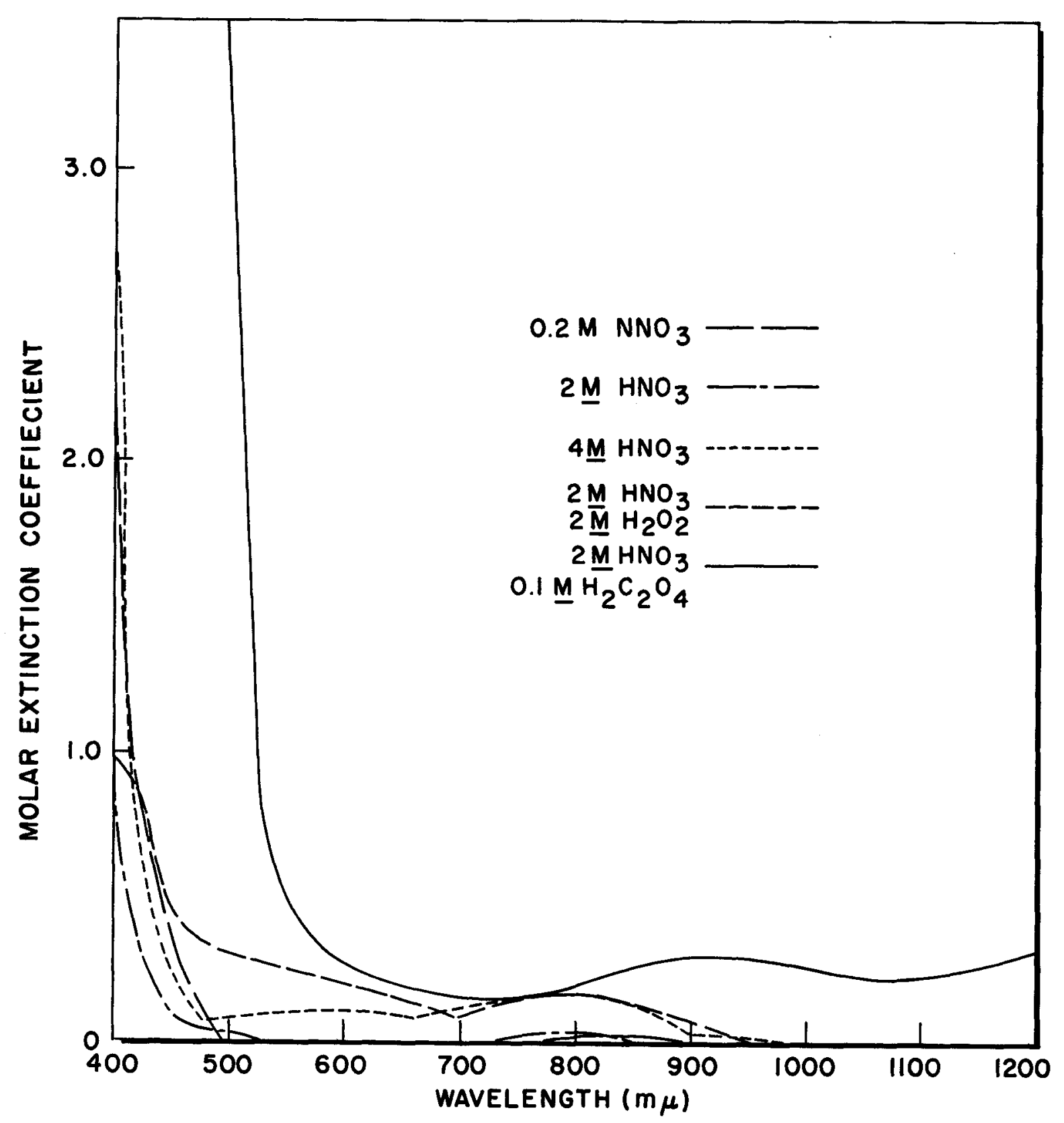

FIGUKE 5

ABSORPTION SPECTRA OF FERRIC IRON 


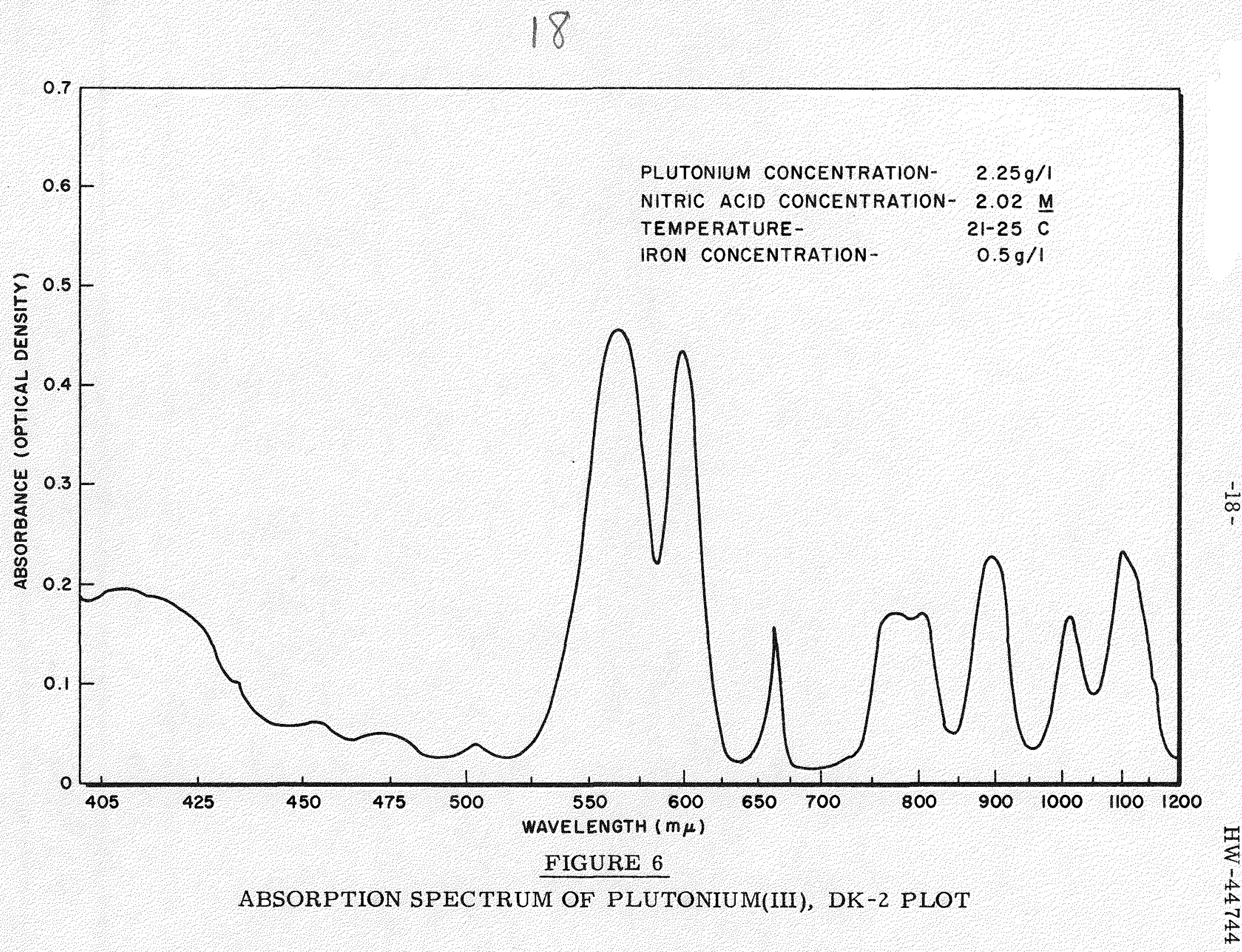




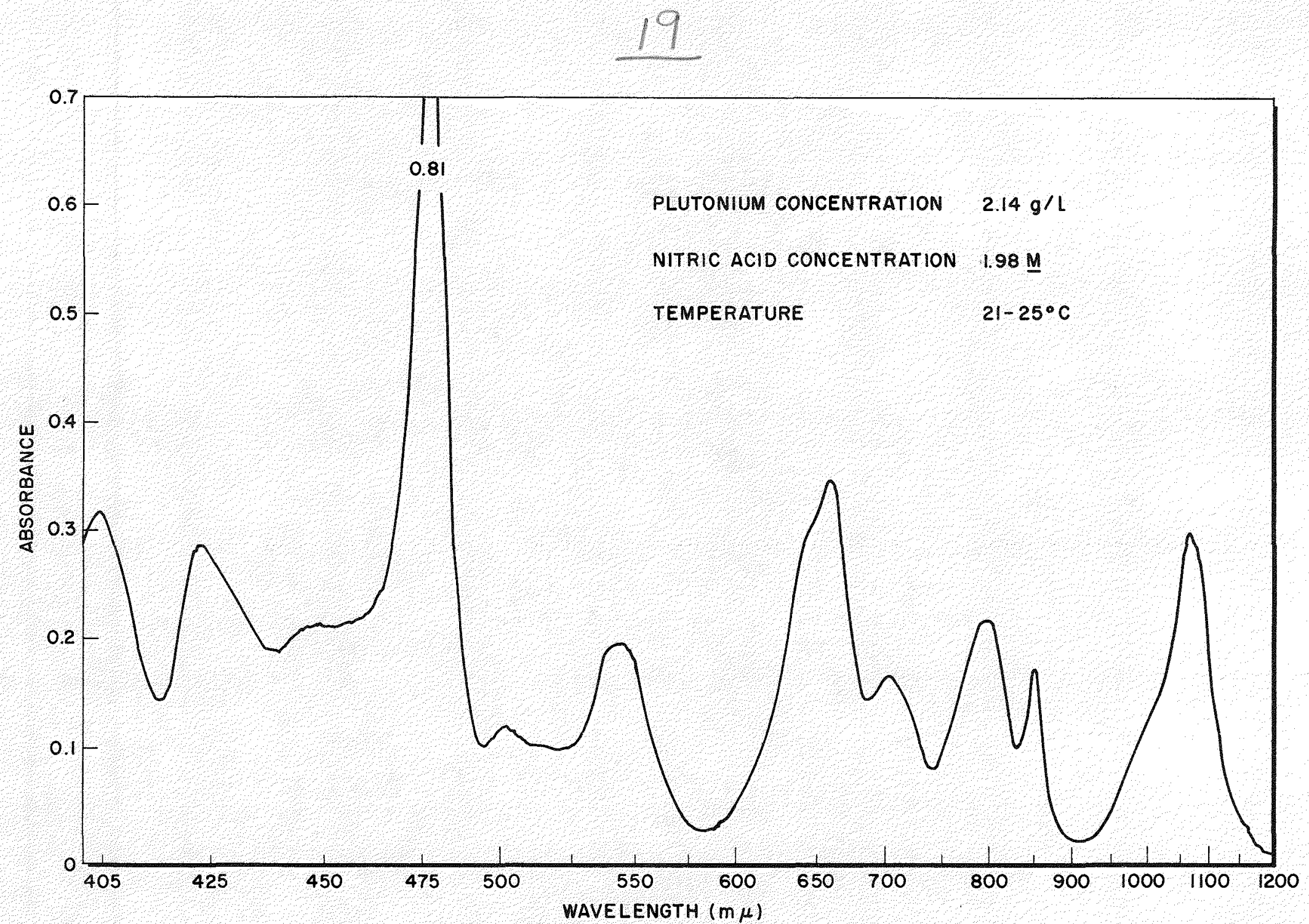

FIGURE 7

ABSORPTION SPECTRUM OF PLUTONIUM(IV), DK-2 PLOT 


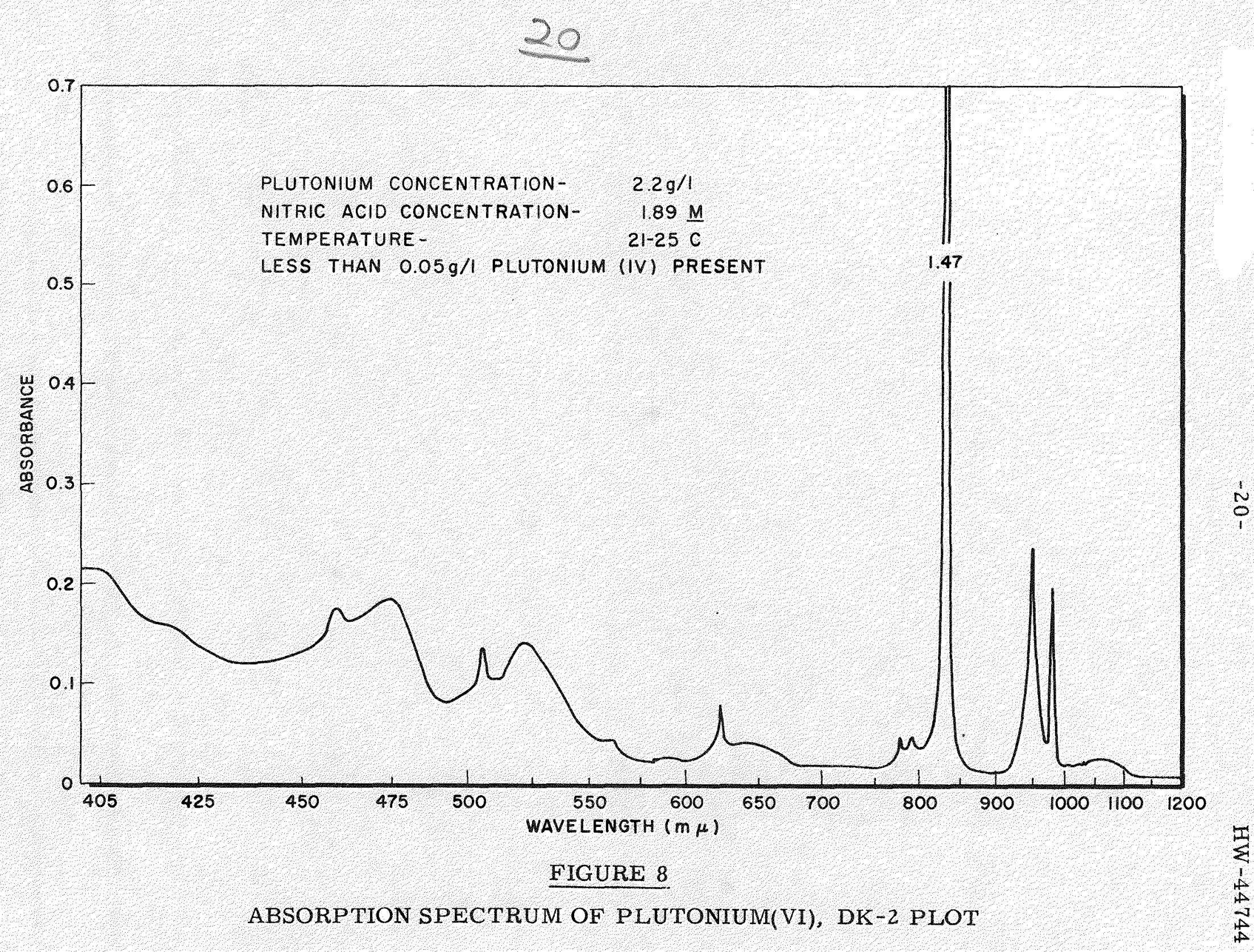




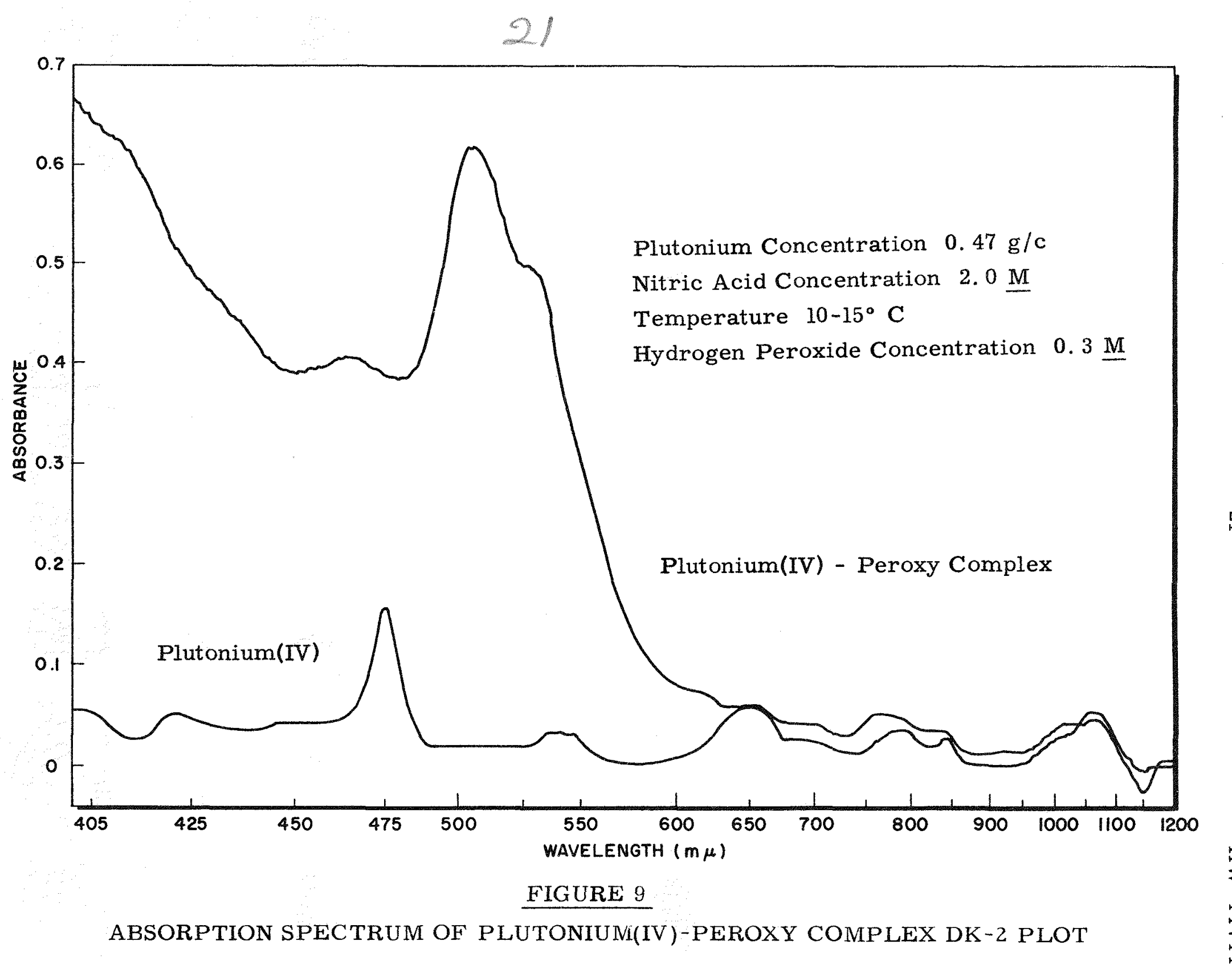




\section{2}

$: \ldots:$

:": : :

$\because \cdots$.

$\because \cdots$

$\because \because \bullet$

$\because . \bullet$

$: . . \therefore$

(......

$\cdots \cdots:$

(.......

:

$\because . .$. :

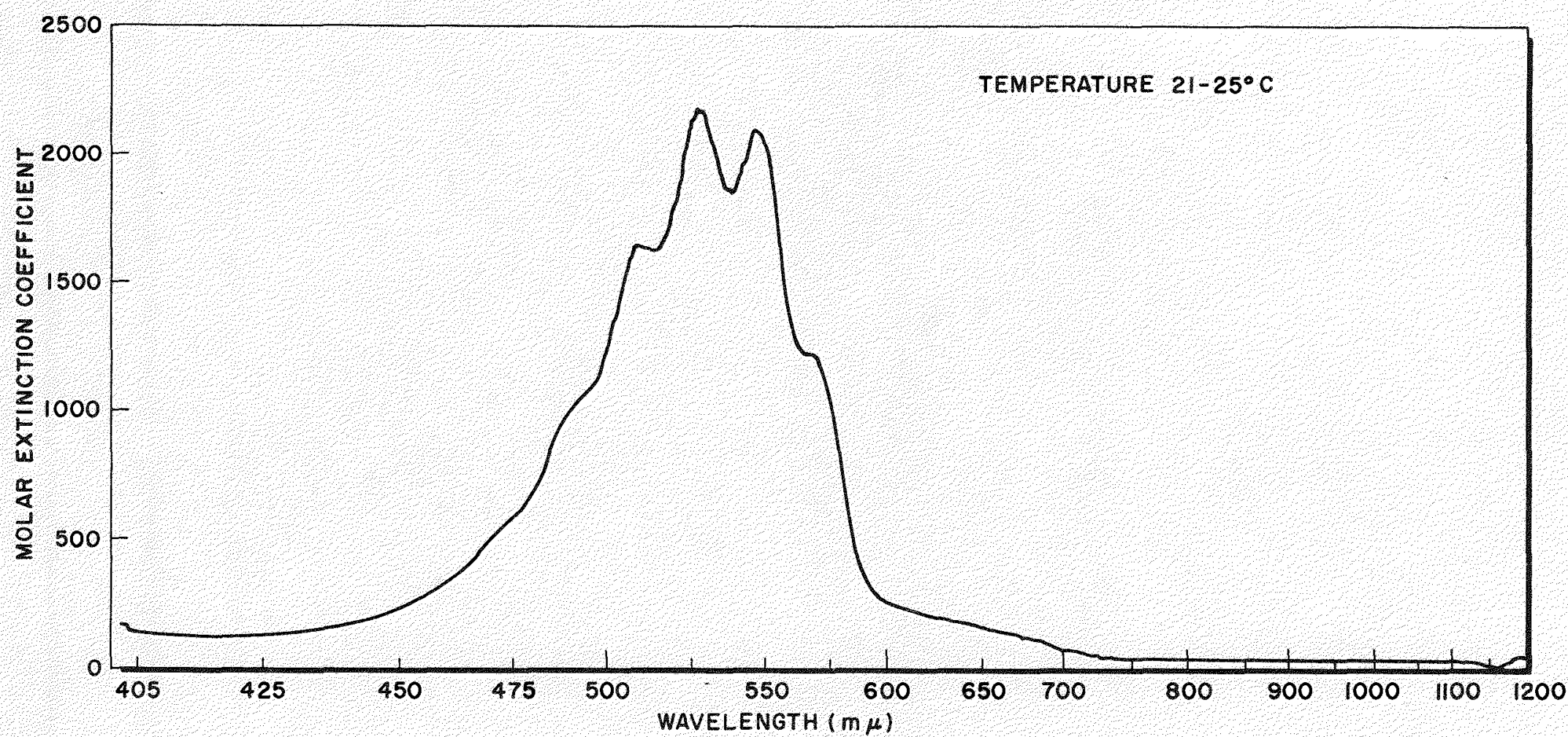

\section{FIGURE 10}

ABSORPTION SPECTRUM OF POTASSIUM PERMANGANATE IN 2 M HNO 